University of Chicago Law School

Chicago Unbound

Journal Articles

Faculty Scholarship

1998

\title{
The Abiding Relevance of Federalism to U.S. Foreign Relations
}

Jack L. Goldsmith

Curtis A. Bradley

Follow this and additional works at: https://chicagounbound.uchicago.edu/journal_articles

Part of the Law Commons

\section{Recommended Citation}

Jack L. Goldsmith \& Curtis A. Bradley, "The Abiding Relevance of Federalism to U.S. Foreign Relations," 92 American Journal of International Law 675 (1998).

This Article is brought to you for free and open access by the Faculty Scholarship at Chicago Unbound. It has been accepted for inclusion in Journal Articles by an authorized administrator of Chicago Unbound. For more information, please contact unbound@law.uchicago.edu. 
is my responsibility and the responsibility of law enforcement and judicial officials throughout the Commonwealth. I cannot cede such responsibility to the International Court of Justice.

Mr. Breard having committed a heinous and depraved murder, his guilt being unquestioned, and the legal issues being resolved against him, and the U.S. Supreme Court having denied the petitions of Breard and Paraguay, I find no reason to interfere with his sentence. Accordingly, I decline to do so. ${ }^{37}$

The International Court of Justice remains seised of the case initiated by Paraguay.

Jonathan I. ChaRney and W. Mrchael REISMAN

\section{The Abiding Relevance of Federalism to U.S. Foreign Relations}

The international law community has heavily criticized the United States' handling of the Breard case. These criticisms are understandable. Perhaps because of the rush of time, the explanations by the Department of Justice and the Supreme Court for failing to stop Breard's execution brushed over important issues of domestic and international law. In addition, Virginia's decision to proceed with the execution, and the federal Government's decision not to block it, may have reflected insufficient respect for international law and institutions. These decisions may also adversely affect U.S. relations with other nations and weaken consular protection of U.S. citizens abroad. These criticisms, however, tell only part of the story. In particular, they do not consider countervailing considerations grounded in the Constitution's allocation of authority between the federal and state governments.

Conventional wisdom tells us that this country's federal structure is irrelevant to the national Government's exercise of its foreign relations powers. This conventional wisdom is reflected in old Supreme Court dicta. ${ }^{1}$ It also pervades foreign relations scholarship. It underlies, for example, the claims that federal courts should apply customary international law as self-executing federal common law that trumps state law; ${ }^{2}$ that the treaty makers can make supreme federal law even if otherwise beyond the authority of the federal Government; ${ }^{3}$ and that courts, on their own initiative, should invalidate state laws affecting foreign relations under a "dormant" preemption rationale."

\footnotetext{
${ }^{7}$ Commonwealth of Virginia, Office of the Governor, Press Office, Statement by Governor Jim Gilmore Concerning the Execution of Angel Breard (Apr. 14, 1998).

'See, e.g., United States v. Pink, 315 U.S. 203, 233 (1942) ("Power over external affairs is not shared by the States; it is vested in the national government exclusively."); United States v. Belmont, 301 U.S. 324,331 (1937) (" [I]n respect of our foreign relations generally, state lines disappear. As to such purpose the State .. does not exist."); The Chinese Exclusion Case, 130 U.S. 581, 606 (1889) ("For local interests the several States of the Union exist, but for national purposes, embracing our relations with foreign nations, we are but one people, one nation, one power."); see also United States v. Curtiss-Wright Export Corp., 299 U.S. 304,316 (1936) ("IS]ince the states severally never possessed international powers, such powers could not have been carved from the mass of state powers but obviously were transmitted to the United States from some other source.").

"See, e.g., Lea Brilmayer, Federalism, State Authority, and the Preemptive Power of International Law, 1994 SUP. C.T. REv. 295, 304, 332 n.109; Louis Henkin, International Law as Law in the United States, 82 MrCH. L. REv. 1555, 1559 (1984); Harold Hongju Koh, Is International Law Really State Law? 111 HaRv. L. REv. 1824, 184647 (1998).

'See, e.g., Louis Henkin, Foreign AfFairs and the UnITEd States Constitution 191, 197 (2d ed. 1996) ("At the end of the twentieth century as at the end of the eighteenth, as regards U.S. foreign relations, the states 'do not exist." "); Lori Fisler Damrosch, The Role of the United States Senate Concerning "Self-Executing" and "Non-Self-Executing" Treaties, 67 CHI.-KeNT L. Rev. 515, 530 (1991); Gerald L. Neuman, The Global Dimension of RFRA, I4 CONST. CoMmentaRy 33, 46-48 (1997).

"See, e.g., Daniel Chow, Limiting Erie in a New Age of International Law: Toward a Federal Common Law of International Choice of Law, 74 Iowa L. REv. 165, 167, 182-83 (1988); John Norton Moore, Federalism and Foreign
} 
In accordance with this conventional wisdom, commentators have tended to view the foreign relations concerns in the Breard case as an absolute value, and to ignore any competing federalism concerns. This attitude is evident in many of the articles in this Agora. It also was evident in the amicus curiae brief filed in the Supreme Court by "professors of law expert in the fields of international law and the application of international law by the courts of the United States." 5 This brief emphasized "the potential consequences for the United States of non-compliance with an ICJ provisional measures ruling" and urged the Court to issue a stay "to ensure that actions of the authorities in Virginia . . . do not inadvertently cause incalculable and irreparable harm on the international plane." ${ }^{16}$ Nowhere in the brief, however, is there any discussion of Virginia's interests in enforcing its criminal laws and retaining control over its crininal justice system, even as factors to be balanced against the potential foreign relations harm.

The federal Government, by contrast, assigned significant weight to Virginia's interests. Although the federal Government took concrete steps to address the foreign relations implications in the Breard case, ${ }^{7}$ it ultimately viewed considerations grounded in federalism as taking precedence. The Solicitor General noted that "the State of Virginia would be harmed by an order preventing it from carrying out its lawfully entered judgment of execution in a timely fashion." 8 The Solicitor General also argued that, even were the ICJ Order binding on the international plane, on the domestic plane "our federal system imposes limits on the federal government's ability to interfere with the criminal justice system of the States."9 In conformity with this view, the Department of State, which signed the Solicitor General's brief, acknowledged "Virginia's right to go forward" with Breard's execution, and "with great reluctance" requested that it not do so. ${ }^{10}$ The lower federal courts expressed concern about foreign relations consequences but, nonetheless, declined to adjudicate Breard's and Paraguay's claims because of the federal habeas corpus procedural default doctrine and the Eleventh Amendment, both of which are premised on respect for state sovereignty. ${ }^{11}$ Finally, the Supreme Court, in declining to stay Breard's execution, stated that, while it was "unfortunate that [the motion for a stay] comes before us while proceedings are pending before the ICJ," it was the Governor of Virginia's prerogative whether to stay the execution and "nothing in [the Court's] existing case law allows us to make that choice for him." 12

These uniform governmental views belie the conventional wisdom concerning the irrelevance of federalism to foreign relations. And it is these views, rather than the conventional wisdom, that are consistent with our constitutional design and history. The

Relations, 1965 Duke L.J. 248, 275-76; Donald T. Trautman, Toward Federalizing Choice of Law, 70 TEx. L. REV. 1715, 1735-36 (1992).

5 See Statement Amicus Curiae of International Law Professors George A. Bermann, David D. Caron, Abram Chayes, Lori Fisler Damrosch, Richard N. Gardner, Louis Henkin, Harold Hongju Koh, Andreas Lowenfeld, W. Michael Reisman; Oscar Schachter, Anne-Marie Slaughter, and Edith Brown Weiss at 1, Republic of Paraguay v. Gilmore, 118 S.Ct. 1352 (1998) (No. 97-1390).

${ }^{6} I d$. at 8-9.

${ }^{7}$ The federal Government acknowledged that the Vienna Convention had been violated, apologized to Paraguay, and took several new steps to ensure that federal, state, and local officials would be aware of, and comply with, the consular notification and consultation provisions of the Vienna Convention. See Brief for the United States as Amicus Curiae at 10, 12, Breard v. Greene, 118 S.Ct. 1352 (1998) (Nos. 97-8:!14, 97-1390).

${ }^{8} I d$. at 48 .

${ }^{9}$ Id. at 51 .

${ }^{10}$ Letter from U.S. Secretary of State Madeleine K. Albright to Governor of Virginia James Gilmore (Apr. 13, 1998).

"See Republic of Paraguay v. Allen, 134 F.3d 622, 627-29 (4th Cir. 1998); Breard v. Pruett, 134 F.3d 615, 619-20 (4th Cir. 1998); Republic of Paraguay v. Allen, 949 F.Supp. 1269, 1272-73 (E.D. Va. 1996); Breard v. Netherland, 949 F.Supp. 1255, 1263 (E.D. Va. 1996).

${ }^{12}$ Breard v. Greene, 118 S.Ct. 1352, 1356 (1998). 
goal of the United States Constitution was to establish a more perfect domestic order. $^{13}$ One means to this end was the creation of a federal structure that allocated authority between a central government and subnational governments. ${ }^{14}$ Another means was the establishment of a governmental system that could successfully conduct foreign relations. It had become clear during the Articles of Confederation period that effective foreign relations required more centralized control. ${ }^{15}$ But the Constitution did not make foreign relations an absolute value, and it did not exclude all state authority that might have an effect on foreign relations. Instead, the Framers addressed the tension between federalism and foreign relations in two ways. First, the Constitution prohibits the states from exercising certain traditional foreign relations powers such as treaty making and war declaration. ${ }^{16}$ Second, it gives the federal political branches broad executory foreign relations powers and creates a supremacy clause, federal executive, and federal judiciary to ensure state compliance with exercises of this authority. ${ }^{17}$ This institutional arrangement treats foreign relations and federalism as competing values and largely leaves it to the federal political branches to decide when a state act has sufficiently adverse effects on foreign relations to require preemption..$^{18}$

Our constitutional history is replete with examples of states engaging in activities that harm our foreign relations. Sometimes the federal political branches decide that the foreign relations interest outweighs decentralized state control over the activity in question, and through treaty, statute, or executive action, seek to invalidate the offending state activity. But on many other occasions, the federal political branches decide that the national interest in foreign relations does not trump the competing federalism concern. $^{19}$

Consider three recent examples. First, the United States has entered into several human rights treaties in the last decade. The Senate has consistently attached both a "federalism understanding" and a "non-self-executing" declaration as a condition of its consent to these treaties. ${ }^{20}$ These provisions are designed to ensure that the treaty obligations have no domestic force and do not alter the balance of authority between the state and federal governments. ${ }^{21}$ Second, although California's multinational corporate tax provoked a diplomatic outcry for decades, opponents of the tax were unable to persuade the federal political branches to preempt it. ${ }^{22}$ In upholding the constitutionality

"See U.S. Const., Preamble; The Federalist No. 1 (Alexander Hamilton).

" See, e.g., THE FEDERAlist Nos. 45, 46 (James Madison).

1 See Frederick W. Marks III, Independence On TrIal: Foreign Affairs and the Making of the ConstituTION (2d ed. 1986); ThE FEDERALIST Nos. 3, 4 (John Jay).

U.S. ConsT. Art. I, \$10.

${ }^{17}$ See, also in this Agora, Carlos Manuel Vázquez, Breard and the Federal Power to Require Compliance with ICJ Orders of Provisional Measures, infra pp. 683, 684-85. It is worth noting that the famous Supreme Court dicta regarding the irrelevance of federalism to foreign relations, see supra note 1 , all came in cases in which the political branches had affirmatively acted to create federal law.

${ }^{11}$ This is not to say that in the foreign affairs area the federal political branches have unlimited authority to preempt the states. The Constitution creates a federal Government of limited and enumerated powers, and it reserves to the states and the people the powers not delegated to the federal Government. See, e.g., City of Boerne v. Flores, 117 S.Ct. 2157, 2162 (1997); United States v. Lopez, 514 U.S. 549, 552 (1995); U.S. CoNST. amend. X. There may be some instances, therefore, in which the federal political branches will lack the authority to override state law, even pursuant to a treaty. See generally Curtis A. Bradley, The Treaty Power and American Federalism, 97 MrCH. L. REv. (forthcoming).

"See generally Dennis J. Palumbo, The States and American Foreign Relations (1960); Jack L. Goldsmith, Federal Contrs, Foreign Affairs, and Federalism, 83 VA. L. REv. 1617, 1650-58 (1997).

${ }^{34}$ See, e.g., U.S. Senate Resolution of Advice and Consent to Ratification of the International Covenant on Civil and Political Rights, 138 CONG. REC. S4781 (daily ed. Apr. 2, 1992), reprinted in 89 AJL 109, 111 (1995).

${ }^{21}$ See Peter J. Spiro, The States and International Human Rights, 66 ForDHAM L. REv. 567, 574-75 (1997).

2 See Brlin Hocking, Localizing Foreign Policy: Non-Central Governdents and Mulmilayered DemocRACX 130-51 (1993). 
of the tax against the charge that it adversely affected foreign relations and frustrated the United States' ability to "speak with one voice" in foreign affairs, the Supreme Court emphasized that it was the job of "Congress-whose voice, in this area, is the Nation'sto evaluate whether the national interest is best served by tax uniformity, or state autonomy."23 Third, notwithstanding the foreign relations interests at stake, the political branches were sensitive to the federalism concerns associated with the GATT and NAFTA trade agreements. As a result, the implementing statutes for these agreements provide for a federal-state consultation process and allow only the federal Government to challenge state laws as being in violation of the agreements. ${ }^{24}$ In these and many other foreign relations situations, the federal Government takes into account respect for state sovereignty in computing the national interest.

This brings us back to the Breard case. There was substantial uncertainty in the case regarding whether the United States was obligated under international law to stay the execution, ${ }^{25}$ and, if so, what effect such an obligation had in the U.S. legal system. In the face of this uncertainty, there was room for disagreement over which valueaccommodation of the various foreign relations interests in the case or respect for Virginia's sovereignty-was more important to the national interest. The Constitution leaves the resolution of such an issue largely to the elected officials in the federal Government. ${ }^{26}$ The President and the Senate had entered into several treaties relevant to the Breard litigation. Taken alone, these treaties might have preempted state law. ${ }^{27}$ It is well settled, however, that for domestic purposes, a later-enacted federal statute prevails over a prior inconsistent treaty. ${ }^{28}$ And in large part out of federalism and related concerns, Congress decided in the subsequent Antiterrorism and Effective Death Penalty Act (with exceptions not relevant to Breard) that a federal court should not hold an evidentiary hearing for habeas claims based on a treaty violation where the petitioner

\footnotetext{
${ }^{23}$ Barclays Bank PLC v. Franchise Tax Bd., 512 U.S. 298, 331 (1994). This decision may have eliminated the remnants of the dormant foreign affairs preemption doctrine announced in Zschernig v. Miller, 389 U.S. 429 (1968). See 512 U.S. at 332 (Scalia, J., concurring); Curtis A. Bradley \& Jack L. Goldsmith, Customary International Law as Federal Common Law: A Critique of the Modern Position, 110 HARV. L. REv. 815, 865 (1997); Goldsmith, supra note 19, at 1699-1701. Professor Kirgis suggests in this Agora that Zschernig is still good law, and that it "appl[ies] to the Breard situation" to the extent that it is properly read as "prohibit[ing] states from 'intruding' on the exclusive national authority in foreign affairs." Frederic L. Kirgis, Zschernig v. Miller and the Breard Matter, infra p. 704, 707. Even if Zschernig retained such vitality, however, it is hard to see how it would be relevant to the Breard litigation, where extant federal statutes and the federal Executive supported Virginia's nondiscriminatory application of its rules limiting postconviction relief.

${ }^{24}$ See 19 U.S.C. $\$ 3512$ (1994) (GATT); 19 U.S.C. \$3312 (NAFTA).

${ }^{25}$ The United Nations Charter obligates the United States to "comply with the decision of the International Court of Justice in any case to which it is a party." UN CHARTER Art. 94(1). It is not clear, however, whether the Provisional Measures Order in the Breard case qualifies as a "decision" under this provision. Nor is it clear whether the ICJ intended the Provisional Measures Order to be binding and, if so, what power the ICJ has to issue such an order. See Brief for the United States as Amicus Curiae, supra note 7, at 49-51.

${ }_{26}$ The Constitution may control the resolution of some of these questions through, for example, its limita* tions on federal court jurisdiction in the 11th Amendment. See Breard v. Greene, 118 S.Ct. 1352, 1356 (1998).

${ }_{27}$ It is far from clear, however, that Virginia's exhaustion and procedural default doctrines conflict with the Vienna Convention in a way that would require preemption. The Convention states that the rights it confers "shall be exercised in conformity with the laws and regulations of the receiving State." Vienna Convention on Consular Relations, Apr. 24, 1963, Art. 36(2), 21 UST 77, 596 UNTS 261. As the Supreme Court noted, "By not asserting his Vienna Convention claim in state court, Breard failed to exercise his rights under the Vienna Convention in conformity with the laws of the United States and the Commonwealth of Virginia." Breard, 118 S.Ct. at 1355 (emphasis added). To be sure, the Convention also states that "said laws and regulations must enable full effect to be given to the purposes for which the rights accorded under this Article are intended." Id. It is unclear what "full effect" means here. But it is not self-evident that a limitation on postconviction relief denies full effect to the rights in the Convention, any more than applying such a limitation to U.S. constitutional rights precludes them from having full effect.

${ }^{28}$ See The Chinese Exclusion Case, 130 U.S. 581, 600-02 (1889); Whitney v. Robertson, 124 U.S. 190, 194 (1888); Head Money Cases, 112 U.S. 580, 599 (1884).
} 
has failed to develop the factual basis for the claim in state court. ${ }^{29}$ In addition, the executive branch elected not to pursue other possible remedies against Virginia in the Breard case, in large part because of federalism concerns. The political branches thus viewed foreign relations not as an absolute value but, rather, as one to be weighed against other values, including federalism.

In deciding how to reconcile the competing values of federalism and foreign relations, the political branches must resolve complex trade-offs between domestic and international interests and, in addition, among competing foreign relations priorities. ${ }^{30}$ Sometimes disagreement among the political branches over the relative priority of domestic and international interests can lead to difficult questions about the distribution of foreign relations authority at the federal level. There was no such difficulty in the Breard litigation, however, because the branches of the federal Government were unanimous in believing that it was Virginia's prerogative whether or not to stay the execution. This view can of course be criticized. The key point, however, is that the Constitution contemplates that this is a decision for the political branches to strike. Foreign relations interests must be weighed against competing federalism concerns.

The Breard case thus teaches many lessons. It shows that foreign relations concerns are but one component of the national interest to be weighed against, and sometimes overridden by, other concerns. It stands as an important reminder that the United States has a dualist Constitution that controls its domestic implementation of international obligations. ${ }^{31}$ And it is a signal that, far from being a relic of the past, federalism continues to play a vibrant role in the conduct of U.S. foreign relations.

Curtis A. BRADley AND JaCK L. GoldSMITH*

\section{Provisional Measures, U.S. Treaty Obligations, and the States}

In Paraguay v. United States, the International Court of Justice entered the following Order: The Court "[i]ndicates the following provisional measures: The United States should take all measures at its disposal to ensure that Angel Francisco Breard is not

\footnotetext{
" See 28 U.S.C.A. \$2254(a), (e) (West Supp. 1998); see also Breard, 118 S.Ct. at 1355.

"In the Breard litigation, a decision by the Executive to compel Virginia's compliance with the ICJ Order might well have had an adverse impact on other foreign relations interests by, for example, causing a backlash in the Senate with respect to U.S. payment of dues in the United Nations or participation in the proposed international criminal court. See Anne-Marie Slaughter, On a Foreign Death Row, WASH. Post, Apr. 14, 1998, at A15.

'There are many judicial decisions, in addition to those in the Breard case, that confirm this country's dualist approach to international obligations. See, e.g., Reid v. Covert, 354 U.S. 1, 17 (1957) (plurality) (concluding that treaties and executive agreements are subject to "[t] he prohibitions of the Constitution"); Whitney v. Robertson, 124 U.S. 190, 194 (1888) (holding that a federal statute supersedes a prior inconsistent treaty); GarciaMir v. Meese, 788 F.2d 1446, 1453-54 (11th Cir. 1986) (holding that the President and Congress have the domestic authority to override customary international law); see also United States v. Alvarez-Machain, 504 U.S. $655,668,670$ (1992) (holding that the abduction of a criminal defendant from Mexico, although it "may be in violation of general international law principles," "does not . . prohibit his trial in a court in the United States for violations of the criminal laws of the United States"); Stanford v. Kentucky, 492 U.S. 361, 370 n.1 (1989) (rejecting the argument that the Court should consult international practice in construing the Eighth Amendment because "it is American conceptions of decency that are dispositive"). For additional discussion of the dualist nature of the U.S. relationship with international law, see Curtis A. Bradley, The Breard Case, Our Dualist Constitution, and the Internationalist Conception, 51 STAN. L. REv. (forthcoming 1999).

* Associate Professor, University of Colorado School of Law; and Associate Professor, University of Chicago Law School, respectively.
} 